Psychological Medicine, 1977, 7, 561-563

Printed in Great Britain

\title{
EDITORIAL
}

\section{Better community residential services for the mentally handicapped ${ }^{1}$}

The sociological study of institutions has developed considerably in the past two decades. It has moved from the case studies of mental hospitals (e.g. Stanton \& Schwartz, 1954; Belknap, 1956) and the graphic, speculative typology of Goffman (1961) to empirically based comparative studies of facilities for both the mentally ill and the mentally handicapped (Hewett et al. 1975; Wing \& Brown, 1970; Ullman, 1967; Wing \& Hailey, 1972; Morris, 1969; King et al. 1971; Raynes et al. 1977). All these studies have included among their goals the development of our understanding of the structure and functioning of these institutions so as to facilitate the planning, administration and evaluation of better residential services. Further, since the publication of Better Services for the Mentally Handicapped (DHSS, 1971), it is clear that in the United Kingdom the government supports the provision of a continuum of services for mentally handicapped persons. As part of that continuum there is a commitment to provide residential facilities in the community for those who need such services.

It is now more than a decade since Tizard (1964) demonstrated that mentally handicapped persons can be cared for in either hostels or their own homes if adequate support services are made available for the handicapped individual and his or her family. The growth of residential services in the community has been slow. In 1974 there were 10496 places provided under the National Health Service in homes and hostels in the community (Hansard, 6 July 1976), but there were still 55150 beds in hospitals for the mentally handicapped.

The Department of Health and Social Security currently encourages the development of community facilities and the reduction of hospital beds. At this juncture, however, we should ask two questions. First, where are those leaving hospital going? Secondly, what is the quality of the residential services in which we are proposing to accommodate at least a part of this population?

In a thorough review of research on the handicapped child Pilling notes 'that hostels do not automatically mean that children will have the best type of care possible' (Pilling, 1973). We should still pay heed to her warning. What she says about the care of children equally applies to the care of adults. At this stage rational planning based on data and systematic evaluation is not only possible but essential if better services for the mentally handicapped are to materialize.

It is necessary to know which aspects of organizational structure are related to which aspects of the quality of care if research is to be of assistance in the planning and development of residentoriented care facilities. The feasibility of such planning and evaluation is demonstrated by the findings of a number of research studies. First, there is considerable evidence that many mentally handicapped people can live in the community in small group facilities (Kushlick, 1967). Kushlick's recent work has shown that children in the Wessex hostels spend more time engaged in activity than do their peers in traditional settings. He has also demonstrated that the running cost of these experimental units is on a par with those of the traditional hospital (A. Kushlick, personal communication).

Secondly, a systematic evaluation of the quality of care in a variety of residential settings for the mentally handicapped child has been undertaken by several workers (Raynes \& King, 1968; King et al. 1971). These studies also showed the importance of aspects of the organizational structure, rather than its size or staffing ratios, in determining the quality of care provided in residential settings. The work of Clarke et al. (1975), who examined a wider range of facilities, also stresses the relative unimportance of size, as compared with organizational structure, in determining the quality of care. King et al. (1971) have also begun to delineate key variables in the organizational structure which promoted or inhibited resident centred care. They have already shown how delegation of authority and role diffusion were linked to child centred care.

${ }^{1}$ Address for correspondence: Dr Norma V. Raynes, Institute of Psychiatry, De Crespigny Park, Denmark Hill, London SE5 8AF. 
Some work recently carried out in the United States further demonstrates what we need to avoid in organizational terms if our hostels are not to incorporate the negative, de-humanizing and stultifying qualities of so many institutions. In a study of three unitized institutions for the mentally retarded Raynes et al. (1974) developed a number of ways of measuring the quality of care provided in these settings. Some of the major findings of the study carry important implications for those involved in organizing and providing care for the mentally handicapped in the community.

In these institutions care was found to vary strikingly from one living unit to another. It is probable, and indeed supported by evidence, that hostels for both the mentally retarded and the mentally ill differ in the kind of care they provide (King et al. 1971; Udall \& Corbett, 1977; Hewett et al. 1975; Apte, 1968). Some of the factors which were found to explain the variance in the quality of care in these institutions are likely to account for the variance which has been found to exist in hostels in England.

In the American study the degree of retardation of the residents was strongly linked to the quality of care they received, however that care was assessed and whichever aspects of it were measured. For the less able residents care was more institutionally oriented and more depersonalized than it was for the more able residents. The physical environment provided for the less able was barren; they were talked to less by the staff and their contact with the world beyond the institutions was less frequent. While much of the variance in the quality of care in these settings could have been accounted for by the degree of the residents' handicaps, when that handicap is statistically controlled for, the perception of the direct-care staff's degree of their participation in decision-making becomes a crucial factor in generating personalized, stimulating care for the residents. Where direct-care staff (the equivalent of nursing aides in English hospitals and hostel staff in British community-based facilities) perceive themselves to be involved in deciding matters relating to their own work and the programmes for the residents, they do indeed talk more to the residents and interact with them more frequently and in a personalized way (Raynes et al. 1977).

Long-stay staff in these settings prove to be more controlling in the speech they use to the residents and the care they provide is more institutionally oriented than either the speech or care provided by staff who have been working for less than one year. However, there is no difference in the performance of staff who have been working for many years in an institution and of their shorter-service colleagues, that is those who have been there for less than one year, if the longer-service colleagues have been promoted. To be promoted meant that they had attained the rank of the equivalent of a British charge-nurse. Do those who receive promotion achieve it because they are 'better' providers of care, or does promotion enable them to feel a greater sense of participation in decision-making? Since promotion in these American institutions was determined essentially on the basis of length of service, because of negotiations agreed between the unions and employers, the latter explanation would seem more likely. Age and sex of staff as well as training, of which there was little, had no effect on the quality of care in terms of individual staff speech to residents.

These findings are based on work carried out in large institutional settings. Whether findings from such settings are of relevance to the organization of care in hostels in England is an empirically verifiable question. It is, however, highly unlikely that what promotes good quality care in institutional settings would have the opposite effect in community facilities. Whether we want all hostels to be the same is a question with philosophical, medical, educational and psychological overtones. It is now self-evident, however, that we should avoid some of the more negative attributes of care by capitalizing on the findings of the research briefly summarized here and also research carried out elsewhere by workers concerned with the care of the mentally ill as well as the mentally handicapped in the community, referred to above.

The research briefly summarized has, therefore, shown that: (1) systematic evaluation of existing services is possible; (2) the establishment and monitoring of experimental services is also possible; (3) organizational structure has an effect on the quality of care, for specific variables in the organizational structure can be identified and their mode of action systematically examined. The current economic situation means that we shall continue to have to move slowly in the development of new facilities for the care of the mentally handicapped. We would surely be unwise not to use the situation 
as a positive opportunity to apply the knowledge we have gained through research to plan carefully and evaluate systematically, as well as experiment with alternative forms of community care, so as to meet the diverse needs of the mentally handicapped. Our knowledge of the best way to provide services should then become more sophisticated and of greater use, therefore, to those who have the day-to-day responsibility for the provision of care.

NORMA V. RAYNES

\section{REFERENCES}

Apte, R. Z. (1968). Half-way Houses. Occasional Papers on Social Administration, No. 27. Bell: London.

Belknap, I. (1956). Human Problems of a State Mental Hospital. McGraw Hill: New York.

Clarke, R. V. G., Sinclair, I. \& Tizard, J. (1975). Varieties of Residential Experience. Routledge \& Kegan Paul: London.

Department of Health and Social Security (1971). Better Services for the Mentally Handicapped, Cmnd. 46830. HMSO: London.

Goffman, I. (1961). Asylums. Doubleday Anchor: New York. Hansard (6 July 1976).

Hewett, S., Ryan, P. \& Wing, J. (1975). Living without the Mental Hospitals. Journal of Social Policy 4, 391-404.

King, R. D., Raynes, N. V. \& Tizard, J. (1971). Patterns of Residential Care. Routledge \& Kegan Paul: London.

Kushlick, A. (1967). The Wessex experiment. Comprehensive care for the mentally subnormal. British Hospital Journal and Journal for Social Services Review 77, 1889-1892.

Morris, P. (1969). Put Away. A Sociological Study of Institutions for the Mentally Retarded. Routledge \& Kegan Paul: London.

Pilling, D. (1973). The Handicapped Child. Longman: London.

Raynes, N. V. \& King, R. D. (1968). A measurement of child management in residential institutions for the retarded. In
Proceedings of the First Congress of the International Association for the Scientific Study of Mental Deficiency (ed. B. B. W. Richards), pp. 637-641. Michael Jackson: Reigate.

Raynes, N. V., Pratt, M. W. \& Roses, S. (1974). Final Report: Organizational Structure and Care for the Retarded. Mimeographed report for the National Institute for Child Health and Human Development, Bethesda, Maryland.

Raynes, N. V., Pratt, M. W. \& Roses, S. (1977). Aides' involvement in decision-making and quality of care. American Journal of Mental Deficiency (in the press).

Stanton, A. \& Schwartz, M. (1954). The Mental Hospital. Basic Books: New York.

Tizard, J. (1964). Community Services for the Mentally Handicapped. Oxford University Press: London.

Udall, E. T. \& Corbett, J. A. (1977). A home to go to. Draft Research Report, Institute of Psychiatry, Bethlem Royal and Maudsley Hospital, London.

Ullman, L. P. (1967). Institution and Outcome. Pergamon: London.

Wing, J. K. \& Brown, G. W. (1970). Institutionalism and Schizophrenia. Cambridge University Press: London.

Wing, J. K. \& Hailey, A. M. (1972). Evaluating a Community Psychiatric Service: the Camberwell Register 1964/71. Oxford University Press: London. 